\title{
Radiation Dose Escalation Is Crucial in Anti-CTLA-4 Antibody Therapy to Enhance Local and Distant Antitumor Effect in Murine Osteosarcoma
}

\author{
Wataru Takenaka ${ }^{1}$, Yutaka Takahashi ${ }^{2, *}$, Keisuke Tamari ${ }^{2}$, Kazumasa Minami ${ }^{2}$, \\ Shohei Katsuki ${ }^{1}$, Yuji Seo ${ }^{2}$, Fumiaki Isohashi ${ }^{2}$, Masahiko Koizumi ${ }^{1}$ 遖 and Kazuhiko Ogawa ${ }^{2}$ \\ 1 Department of Medical Physics and Engineering, Osaka University Graduate School of Medicine, Suita, \\ Osaka 565-0871, Japan; takewata216@gmail.com (W.T.); skatsuki@sahs.med.osaka-u.ac.jp (S.K.); \\ koizumi@sahs.med.osaka-u.ac.jp (M.K.) \\ 2 Department of Radiation Oncology, Osaka University Graduate School of Medicine, Suita, Osaka 565-0871, \\ Japan; tamari@radonc.med.osaka-u.ac.jp (K.T.); k_minami@radonc.med.osaka-u.ac.jp (K.M.); \\ seo@radonc.med.osaka-u.ac.jp (Y.S.); isohashi@radonc.med.osaka-u.ac.jp (F.I.); \\ kogawa@radonc.med.osaka-u.ac.jp (K.O.) \\ * Correspondence: ytakahashi@radonc.med.osaka-u.ac.jp; Tel.: +81-6-6879-3482; Fax: +81-6-6879-3484
}

Received: 28 April 2020; Accepted: 10 June 2020; Published: 12 June 2020

\begin{abstract}
We previously reported that a combination of $10 \mathrm{~Gy}$ of X-ray irradiation and dual immune checkpoint blockade with anti-CTLA-4 (C4) and anti-PD-L1 antibodies produced a significant shrinkage of irradiated and unirradiated tumors (abscopal effect) and prolonged overall survival. However, the optimal radiation delivery regimen combined with single immune checkpoint blockade of $\mathrm{C} 4$ for inducing a maximum systemic antitumor response still remains unclear, particularly for patients with osteosarcoma. We used syngeneic $\mathrm{C} 3 \mathrm{H}$ mice that were subcutaneously injected with LM8 osteosarcoma cells into both legs. C4 was administered three times, and one side of the tumor was irradiated by $\mathrm{X}$-ray beams. The optimal radiation dose required to induce the abscopal effect was explored with a focus on the induction of the type-I interferon pathway. Radiation delivered in a single fraction of $10 \mathrm{~Gy}, 4.5 \mathrm{~Gy} \times 3$ fractions $(\mathrm{fx})$, and $2 \mathrm{~Gy} \times 8 \mathrm{f} \times$ with $\mathrm{C} 4$ failed to produce significant inhibition of unirradiated tumor growth compared with monotherapy with C4. Dose escalation to $16 \mathrm{~Gy}$ in a single fraction, or the equivalent hypofractionated dose of $8 \mathrm{~Gy} \times 3 \mathrm{fx}$, which significantly increased secretion of IFN- $\beta$ in vitro, produced a dramatic regression of both irradiated and unirradiated tumors and prolonged overall survival in combination with C4. Furthermore, irradiation at $16 \mathrm{~Gy}$ in both a single fraction and $8 \mathrm{~Gy} \times 3 \mathrm{fx}$ diminished regulatory $\mathrm{T}$ cells in the unirradiated tumor microenvironment. These results suggest that total dose escalation of radiation is crucial in C4 therapy to enhance the antitumor response in both local and distant tumors and prolonged overall survival regardless of fractionation for osteosarcoma.
\end{abstract}

Keywords: radiation; immune checkpoint blockade; abscopal effect; dose escalation; osteosarcoma

\section{Introduction}

Radiotherapy (RT) has been a component of the standard treatment against many types of solid tumors and is highly effective for local control. It has been widely reported that tumor regression is observed, even in distant tumors out of the radiation field, when RT is utilized for patients with multiple metastasis [1-4]. This phenomenon is an immune-mediated event known as the abscopal effect [5-10]. However, the abscopal effect is rarely observed in treatment of cancers by RT alone, both in preclinical models and in clinical practice. Recently, Honjo et al. and Allison et al. discovered PD-1 and CTLA-4 antibodies, respectively, which have revolutionized treatments for patients with multiple metastases in 
various types of cancers, providing a durable long-term response [11-16]. However, the response is observed for only up to $30 \%$ of patients [11-16]. Together with the radiation-induced abscopal effect, combined therapy with immune checkpoint blockade has been found to be an effective strategy for some cancers [17-23], although the optimal combination strategy, especially in the context of radiation delivery (e.g., sequence, total dose, and fractionation) remains unclear for some types of tumors.

Osteosarcoma is one of the most common cancers in adolescence and young adults and often leads to lethal pulmonary metastasis [24-26]. The current standard treatment for osteosarcoma is a combination of radical surgery and chemotherapy such as doxorubicin and methotrexate [26-28]; however, the efficacy is still limited, indicating that developing a novel therapeutic strategy is an emergent issue $[29,30]$. Recently, our group reported that dual immune checkpoint blockade of anti-PD-L1 (P1) and anti-CTLA-4 (C4) antibodies combined with single delivery of 10 Gy X-ray irradiation enhanced the systemic antitumor response both at local and distant sites in murine osteosarcoma [31]. Although this triple combination therapy produced a fascinating treatment outcome without significant adverse effect in the preclinical model, treatment using dual immune checkpoint inhibitors significantly increases the risk of immune-related adverse events for patients [32-34]. Moreover, considering the medical expense, exploring novel therapeutic strategies with single immune checkpoint blockade without attenuating treatment efficacy is an urgent issue. Although the addition of radiation to single immune checkpoint blockade therapy is expected to bring an enhanced antitumor effect to some extent, the optimal radiation delivery regimen, including total radiation dose and fractionation, required to exert a greater systemic response remains unclear, particularly for osteosarcoma. On the basis of the recent evidence that the induction of type-I interferons is associated with radiation-induced antitumor immunity [35], we show that a high, but not intermediate, dose of local irradiation is necessary to exert the maximum efficacy of the anti-CTLA-4 antibody (C4) for osteosarcoma.

\section{Results}

\subsection{C4 Monotherapy Transiently Inhibits Tumor Growth}

We first investigated whether monotherapy of C4 was effective for suppressing osteosarcoma in an LM8 tumor-bearing mouse model (Figure 1a). Significant but transient regression was observed on day 18 ( $p=0.0478$ ) of C4 monotherapy (Figure 1b). However, the overall survival of the C4 group was not significantly prolonged compared with that of the No Tx group $(p=0.5957)$, indicating that three cycles of C4 monotherapy contribute to tumor growth delay to some extent but not to prolonged overall survival (Figure 1c).

(a)

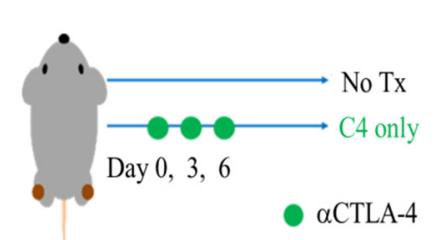

(b)

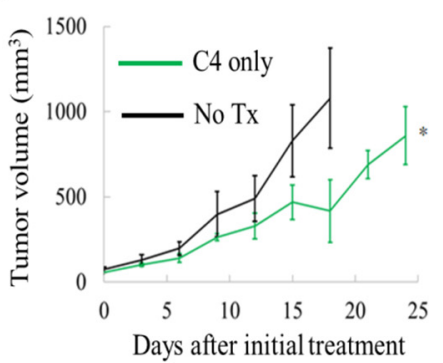

(c)

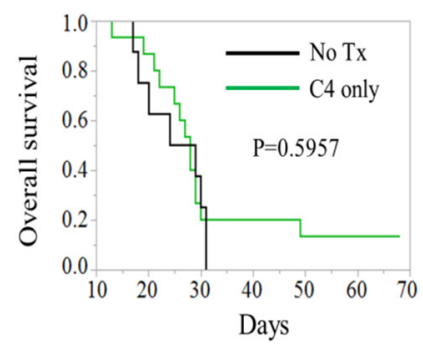

Figure 1. Efficacy of anti-CTLA-4 antibody (C4) for the treatment of murine osteosarcoma. (a) Schema of the treatment schedule. Treatment was initiated from the date defined as day 0 on which tumor volume reached $\geq 14 \mathrm{~mm}^{3}$. C4 was administered three times every 3 days. (b) Tumor volume change from the initial treatment. (c) Overall survival by the Kaplan-Meier method. Error bars represents SEM. * $p<0.05$. 


\subsection{Intermediate Radiation Dose with Concurrent C4 Therapy Does Not Adequately Enhance the Antitumor Efficacy}

We previously demonstrated that the concurrent triple combination of P1, C4, and 10 Gy of X-ray irradiation enhanced the antitumor efficacy for both local and distant tumors [31]. Therefore, we investigated whether single immune checkpoint blockade of $\mathrm{C} 4$ with concurrent $\mathrm{X}$-ray irradiation at $10 \mathrm{~Gy}$, and its equivalent doses in fractionation determined by a linear-quadratic model [36,37], $4.5 \mathrm{~Gy} \times 3 \mathrm{fx}$, and $2 \mathrm{~Gy} \times 8 \mathrm{fx}$, still enhanced antitumor efficacy (Figure 2a). Despite the direct irradiation at the above dose levels to the tumor, only a slight delay in tumor growth was observed in the irradiated (IR) tumor compared with the C4 only group (Figure 2b). No significant difference was observed in the volume of the unirradiated (UnIR) tumor on the other side of the leg (Figure 2c). To analyze the likelihood of the abscopal effect, we examined the ratio of complete and partial response $(\mathrm{CR}+\mathrm{PR})$, defined as the longest diameter on day 21 that was shorter than that on the day of the initial treatment. Response was observed in 3 of 14 mice in the $\mathrm{C} 4$ only group, and addition of $10 \mathrm{~Gy}, 4.5 \mathrm{~Gy} \times 3 \mathrm{fx}$, or $2 \mathrm{~Gy} \times 8 \mathrm{fx}$ to $\mathrm{C} 4 \mathrm{did}$ not increase the response. Specifically, 1 of 15 in the C4/Conc-10 Gy group, 1 of 7 in the C4/Conc- $4.5 \mathrm{~Gy} \times 3$ fx group, and 0 of 6 in the C4/Conc-2 Gy $\times 8$ fx group exhibited CR + PR in the abscopal site (Figure 2d). No statistical significance was observed among these groups. Furthermore, the comparison of the responder in the abscopal tumor between the $\mathrm{C} 4$ monotherapy and $\mathrm{C} 4$ with the intermediate-dose regimen $(10 \mathrm{~Gy}, 4.5 \mathrm{~Gy} \times 3 \mathrm{fx}$, and $2 \mathrm{~Gy} \times 8 \mathrm{fx})$ revealed no significant differences (Figure S1). The long-term follow-up revealed that no significant survival benefit was observed in either combination therapy compared with $\mathrm{C} 4$ only. The median survival times of C4 only, C4/Conc-10 Gy, C4/Conc-4.5 Gy $\times 3 \mathrm{fx}$, and C4/Conc-2 Gy $\times 8 \mathrm{fx}$ were 27.5, 29,33 , and 27.5 days, respectively (Figure 2e).

(a)

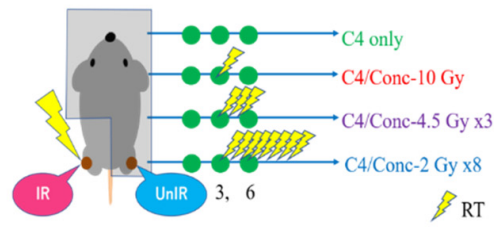

(b) IR

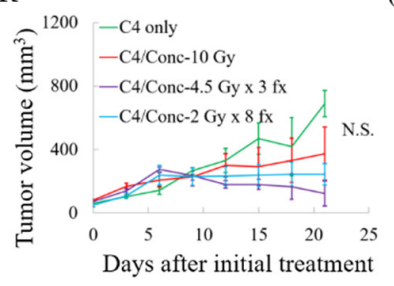

(c) UnIR

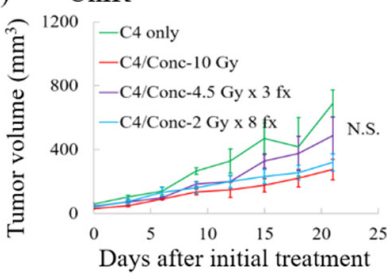

(d)

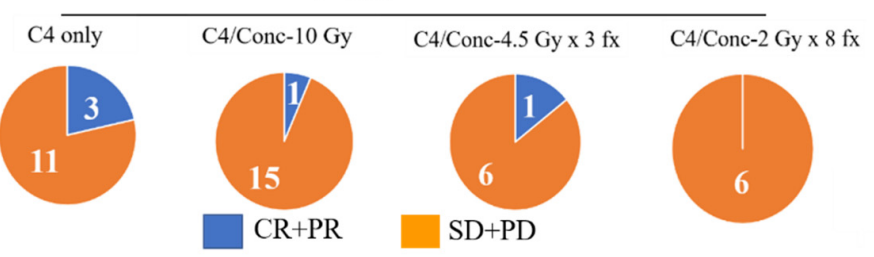

(e)

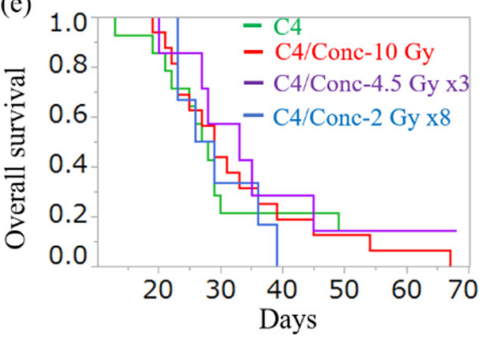

Figure 2. Antitumor efficacy of C4 therapy with or without X-ray at $10 \mathrm{~Gy}$ or its equivalent dose in normal fraction or hypofraction. (a) Schema of the treatment schedule with mouse setup to irradiate one side of the tumor, with the other protected using $\geq 4 \mathrm{~mm}-\mathrm{Pb}$ lead plates. Treatment was initiated on day 0 when tumors reached a size of $14 \mathrm{~mm}^{3}$. C4 was administered on days 0,3 , and 6 . (b,c) Tumor volume change after initial treatment of IR and UnIR tumors. (d) Pie charts showing the ratio between complete and partial response $(C R+P R$; the longest diameter on day $21 \leq$ that on the day of the initial treatment) and stable and progressive disease (SD + PD) of the abscopal tumor. (e) Overall survival by the Kaplan-Meier method. Error bars represent SEM. The data of C4 only are shared with Figure 1 because the materials and procedures were exactly the same. 


\subsection{Dose Escalation Dramatically Induces the Type-I Interferon Pathway In Vitro}

Since the C4 treatment with a single fraction of $10 \mathrm{~Gy}$ and the equivalent fractionated doses showed no significant reduction in the IR and UnIR tumors or extension of overall survival compared with the C4 only group, we next examined whether further dose escalation increased the antitumor immunity. A recent study demonstrated that high-dose hypofractionated irradiation at $8 \mathrm{~Gy} \times 3 \mathrm{fx}$ significantly induced immune response through type-I interferon pathways both in vitro and in vivo [35]. Accumulation of the cytosolic double-stranded DNA (dsDNA) induced by DNA damage triggers IFN- $\beta$ production through the cyclic GMP-AMP synthase (cGAS) stimulator of the interferon gene (STING) pathway [38-41]. Our in vitro results showed that irradiation at 10 Gy in a single fraction significantly increased the cytoplasmic dsDNA level compared with 0 Gy, but a higher expression level was observed at $16 \mathrm{~Gy}$ in a single fraction. Notably, $8 \mathrm{~Gy} \times 3 \mathrm{fx}$ provided the highest dsDNA level (Figure 3a). The expression of cGAS, a sensor protein of cytosolic DNA, was upregulated in a dose-dependent manner. Notably, $8 \mathrm{~Gy} \times 3 \mathrm{fx}$ dramatically increased the expression level. STING, which is activated by cGAS, is strongly expressed in a dose-dependent manner. Importantly, its downstream signal, phosphorylation of interferon regulatory factor 3 (phospho-IRF3), is expressed to a greater extent by $16,30 \mathrm{~Gy}$, and $8 \mathrm{~Gy} \times 3 \mathrm{fx}$ irradiation than 0 Gy but not by 2 Gy and $10 \mathrm{~Gy}$ irradiation (Figure 3b, Figure S2).

(a)

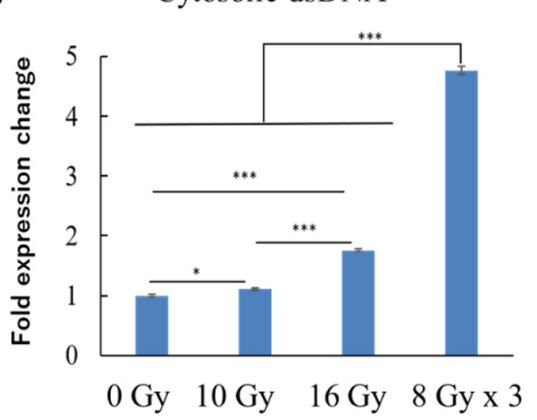

(c)

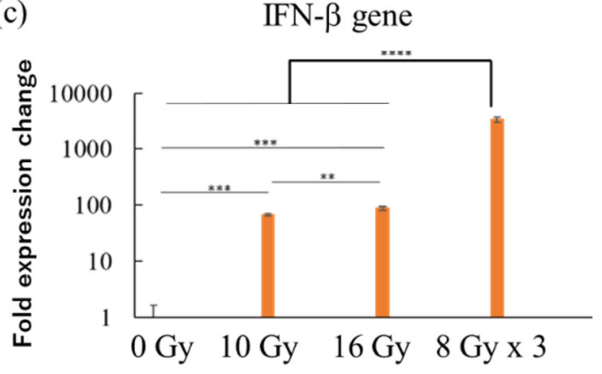

(b)

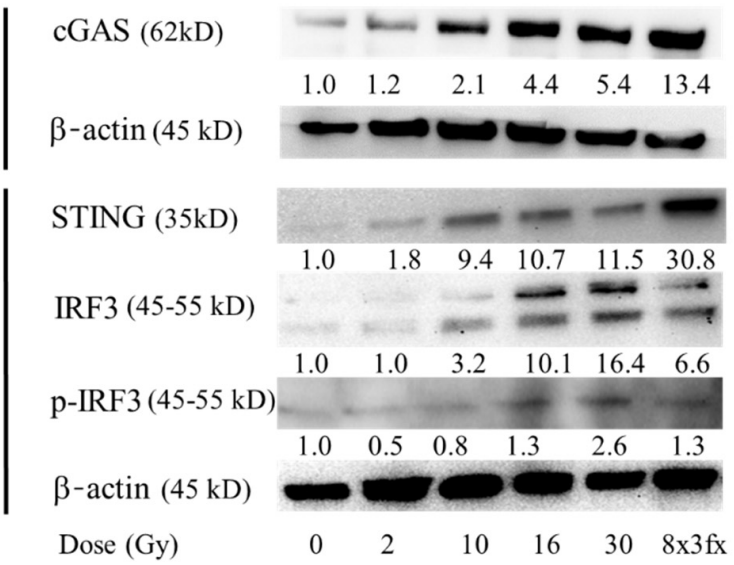

(d)

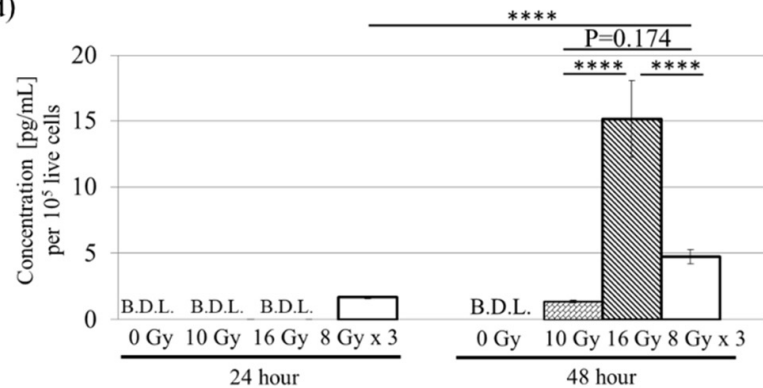

Figure 3. Analysis of the type-I interferon pathway in vitro. (a) Fold expression change in cytosolic double-stranded DNA expression $24 \mathrm{~h}$ after the last delivery of irradiation. (b) Expression level of type-I interferon-related proteins by Western blotting $24 \mathrm{~h}$ after the last delivery of irradiation. Values on each band represent the area density of the proteins normalized to a loading control ( $\beta$-actin). Untrimmed pictures in the Western blot are provided in Supplemental Figure S3. (c) Fold expression change of Ifnb1 coding IFN- $\beta 24 \mathrm{~h}$ after the last delivery of irradiation. (d) Concentration of IFN- $\beta$ in the cell culture supernatant 24 and $48 \mathrm{~h}$ after the final delivery of irradiation at $0 \mathrm{~Gy}, 10 \mathrm{~Gy}, 16 \mathrm{~Gy}$, or $8 \mathrm{~Gy} \times 3 \mathrm{fx}$. Error bars represent SD. ${ }^{*} p<0.05$ comparing each radiation dose. ${ }^{* *} p<0.01,{ }^{* * *} p<0.001,{ }^{* * * *} p<0.0001$. Abbreviation: B.D.L.: bellow detection limit.

We next examined the change in expression of Ifnb1 coding IFN- $\beta$. Ifnb1 was increased in a dose-dependent manner by 68-fold, 88-fold, and 3304-fold at 10, 16 Gy, and 8 Gy $\times 3$ fx compared with 
that at the 0 Gy sample, respectively (Figure $3 c$ ). Secretion of IFN- $\beta$ into the cell culture supernatant was also increased by $8 \mathrm{~Gy} \times 3 \mathrm{fx}$ but was not detected by 10 or $16 \mathrm{~Gy}$ irradiation $24 \mathrm{~h}$ after the final delivery of irradiation (Figure $3 \mathrm{~d}$ ). However, the increase was more notable at $16 \mathrm{~Gy}$ than $8 \mathrm{~Gy} \times 3 \mathrm{fx}$ and $10 \mathrm{~Gy} 48 \mathrm{~h}$ after irradiation (Figure 3d), whereas no increase was observed $24 \mathrm{~h}$ after irradiation at a low dose of $2 \mathrm{~Gy}$ nor at an extremely high dose of $30 \mathrm{~Gy}$. However, $30 \mathrm{~Gy}$ irradiation exhibited significantly increased secretion $48 \mathrm{~h}$ after the irradiation, whereas $2 \mathrm{~Gy}$ did not (Figure S2). Due to the possible normal tissue toxicity at $30 \mathrm{~Gy}$ irradiation in a single delivery in vivo, we used $8 \mathrm{~Gy} \times 3 \mathrm{fx}$ and 16 Gy for further in vivo experiments.

\subsection{Concurrent Combination of Anti-CTLA-4 and High-Dose Irradiation Dramatically Enhanced Antitumor Efficacy at Both Local and Distant Sites}

We next investigated whether a higher radiation dose provided a robust antitumor effect both at the in-field and abscopal lesion in vivo (Figure 4a). IR tumors were eradicated in 14 of 17 mice in the C4/Conc- 8 Gy $\times 3$ fx group and in 9 of 11 mice in the C4/Conc-16 Gy group, which was a significantly higher response than the $\mathrm{C} 4$ only group (Figure $4 \mathrm{~b}$ ).

(a)

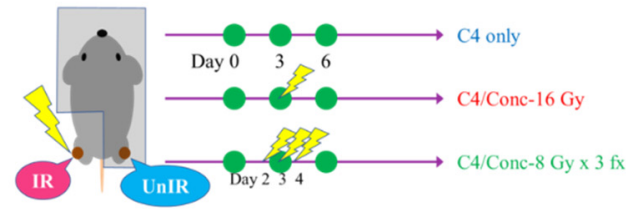

(b)

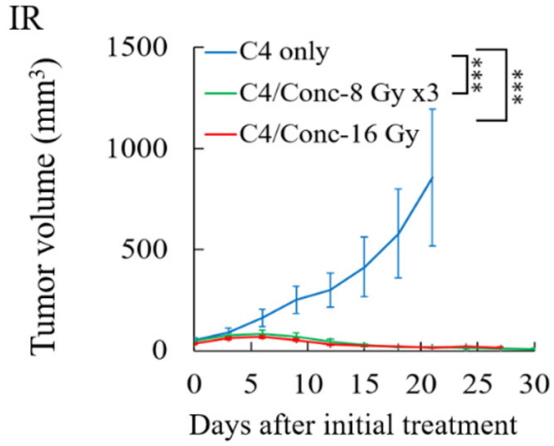

(d)

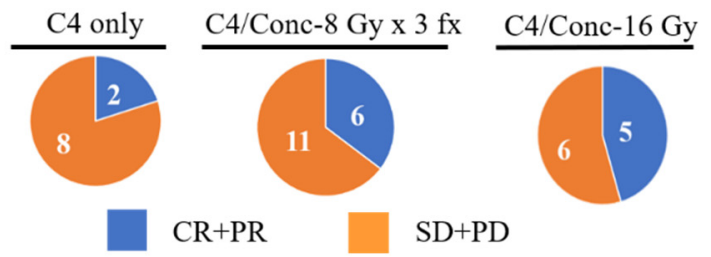

(c) UnIR

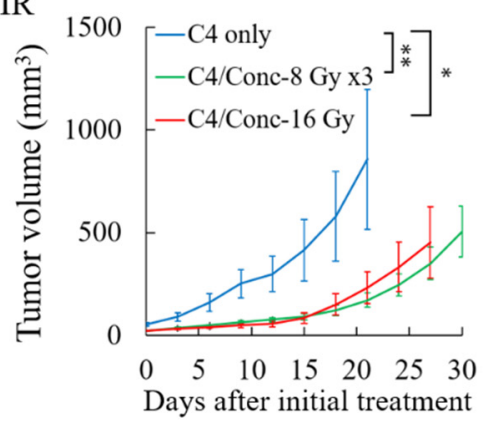

(e)

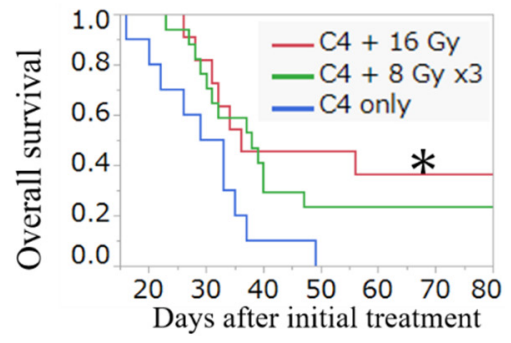

Figure 4. Antitumor efficacy of C4 therapy with or without X-ray at $16 \mathrm{~Gy}$ or its equivalent dose in hypofraction. (a) Scheme of the treatment schedule. Day 0 was defined as the day when tumors reached a size of $14 \mathrm{~mm}^{3}$. (b) Tumor volume change at the irradiated side and (c) unirradiated side. (d) Pie charts showing the ratio between complete and partial response (CR + PR; the longest diameter on day $21 \leq$ that on the day of the initial treatment) and stable and progressive disease (SD + PD) of the abscopal tumor. (e) Overall survival using the Kaplan-Meier method. Error bars represent SEM. ${ }^{*} p<0.05,{ }^{* *} p<0.01,{ }^{* * *} p<0.001$.

Interestingly, the UnIR tumor volume was also significantly decreased in both the C4/Conc-8 Gy $\times 3 \mathrm{fx}$ and C4/Conc-16 Gy groups (Figure 4c). Only 2 in 10 mice in the C4 only group responded in the abscopal tumors, whereas 6 in 17 mice and 5 in 11 mice responded in the C4/Conc- $8 \mathrm{~Gy} \times 3 \mathrm{fx}$ and C4/Conc-16 Gy groups, respectively (Figure 4d). Moreover, the overall survival was significantly prolonged in the $8 \mathrm{~Gy} \times 3 \mathrm{fx}$ and $16 \mathrm{~Gy}$ combined with $\mathrm{C} 4$ therapy groups compared with the $\mathrm{C} 4$ only 
group. The median survival times of the $\mathrm{C} 4$ only, C4/Conc- $8 \mathrm{~Gy} \times 3 \mathrm{fx}$, and C4/Conc- $16 \mathrm{~Gy}$ groups were 31,38 , and 36 days, respectively (Figure 4 e). Sequential combination therapy with irradiation at $8 \mathrm{~Gy} \times 3 \mathrm{fx}$ prior to $\mathrm{C} 4$ administration (C4/Pre- $8 \mathrm{~Gy} \times 3 \mathrm{fx})$ exhibited comparable antitumor efficacy in both the IR and UnIR tumors (Figure S4a-c).

The direct comparison of the abscopal effect between the intermediate-dose regimen $(10 \mathrm{~Gy}, 2 \mathrm{~Gy} \times 8 \mathrm{fx}$, and $4.5 \mathrm{~Gy} \times$ fraction) and the high-dose regimen $(16 \mathrm{~Gy}$ and $8 \mathrm{~Gy} \times 3 \mathrm{fx})$ with $C 4$ revealed a significant tumor volume reduction following treatment with the high-dose regimen (Figure 5a). Furthermore, the proportion of the responders at the abscopal sites in the intermediate regimen was 2/29, whereas that in the high-dose regimen was $11 / 28$ (Figure 5 b); based on this, the overall survival was significantly prolonged (Figure $5 \mathrm{c}$ ).

(a)

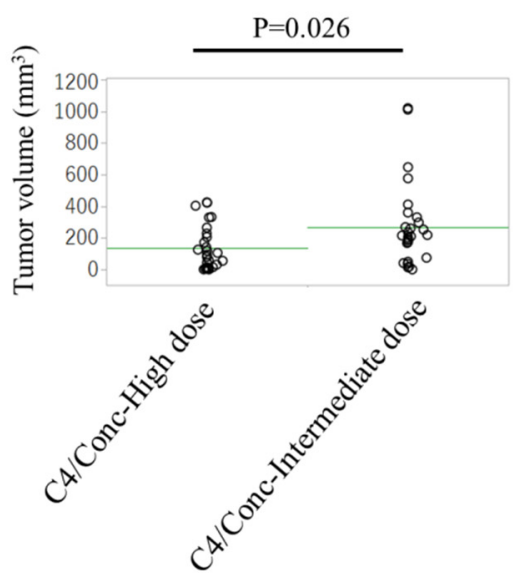

(b)

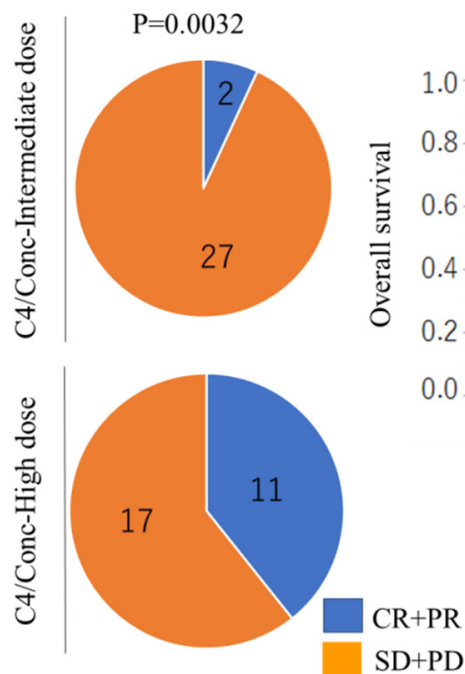

(c)

$\mathrm{DP}+\mathrm{PD}$

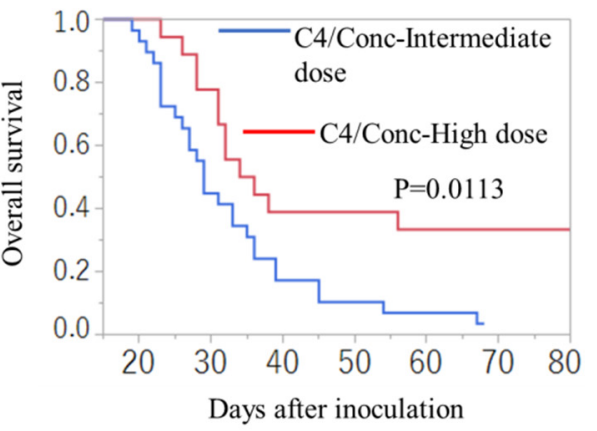

(d)

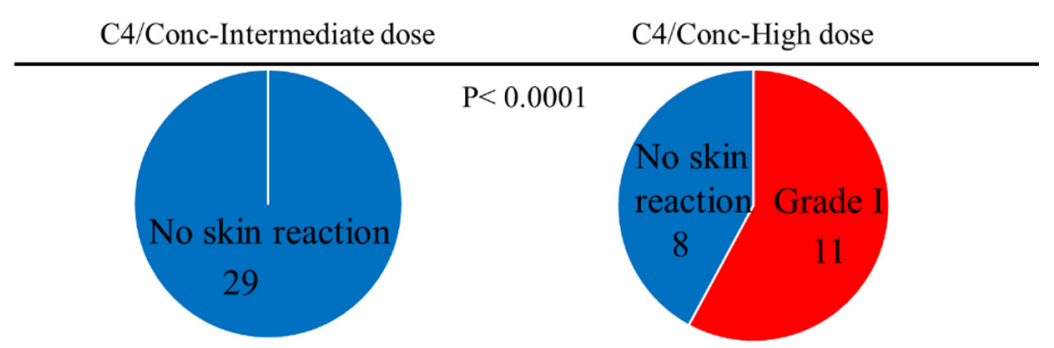

Figure 5. Comparison of the treatment efficacy in the abscopal tumor and overall survival between intermediate-dose $(10 \mathrm{~Gy}, 4.5 \mathrm{~Gy} \times 3 \mathrm{fx}$, and $2 \mathrm{~Gy} \times 8 \mathrm{fx})$ and high-dose $(16 \mathrm{~Gy}, 8 \mathrm{~Gy} \times 3 \mathrm{fx})$ regimens. (a) Comparison of the treatment efficacy in abscopal tumor volume. (b) Pie charts showing the ratio between complete and partial response (CR + PR; the longest diameter on day $21 \leq$ that on the day of the initial treatment) and stable and progressive disease (SD + PD) of the abscopal tumor. (c) Overall survival by the Kaplan-Meier method. (d) Pie charts showing the ratio between Grade I acute skin reaction and no acute reaction of the irradiated tumors. The data of Figures 2 and 4 were compared because the materials and procedures were exactly the same. Error bars represent SEM.

Radiation-induced skin reaction based on the Common Terminology Criteria for Adverse Events v3.0. [42] revealed that Grade 1, which is defined as skin changes such as dry desquamation with generalized erythema, was not observed in mice with the C4/Conc-intermediate dose, whereas 11/19 mice experienced a Grade I skin reaction (Figure 5d). However, the skin reaction 
recovered within nine days. No radiation-induced systemic symptoms, including apparent slimming and prostration after treatments, were observed in mice in both treatment regimens.

\subsection{Radiation Dose Escalation Alters the Immune Microenvironment}

Since higher dose irradiation enhanced the antitumor efficacy of $\mathrm{C} 4$ and prolonged overall survival, flow cytometric analysis was performed to investigate the immune microenvironment in IR and UnIR tumors (Figure 6a). Although regulatory T cells (Tregs) play a crucial role in immune tolerance [43], in the tumor microenvironment, Tregs negatively contribute to the antitumor immune response [43]. Our flow cytometric analysis showed that CD4 + Foxp3 + Treg infiltration in IR tumors was significantly diminished with a single-fraction X-ray of $10 \mathrm{~Gy}, 16 \mathrm{~Gy}$, and $8 \mathrm{~Gy} \times 3 \mathrm{fx}$ (Figure 6b). Interestingly, Tregs were significantly reduced in UnIR tumors by $16 \mathrm{~Gy}$ and $8 \mathrm{~Gy} \times 3 \mathrm{fx}$ irradiation but not with 10 Gy irradiation (Figure 6c).

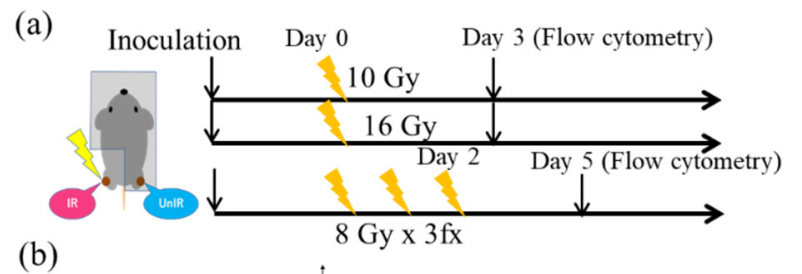

(b) Irradiated
tumors
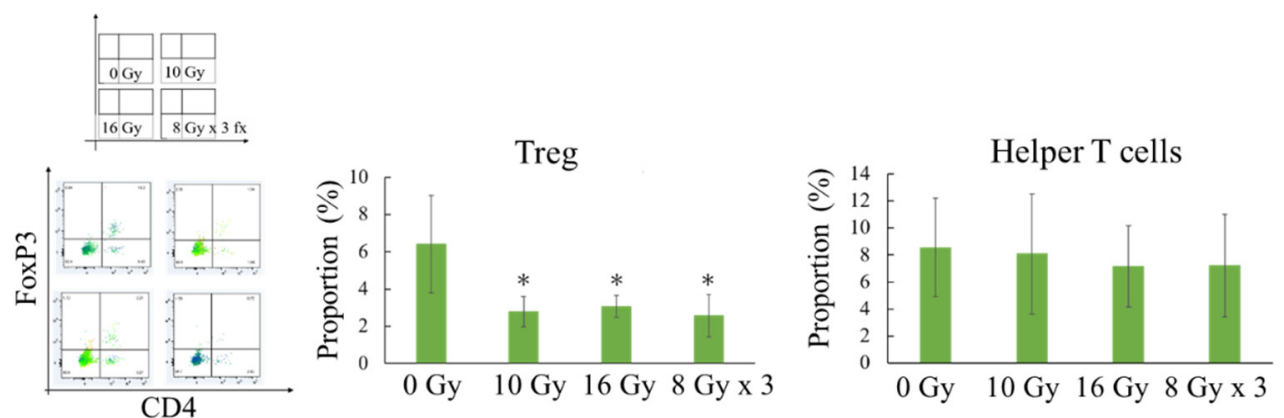

(c)
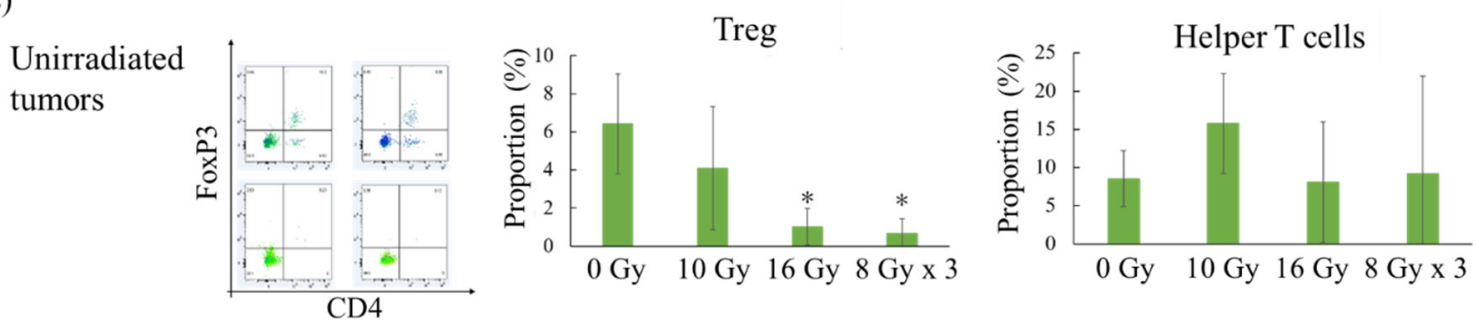

Figure 6. Alteration of the immune microenvironment. (a) Schematic diagram for flow cytometry. (b) Representative dot plots of $\mathrm{CD} 4$ and FoxP3. The middle and right graphs represent the quantifications of CD4 + FoxP3 + Treg and CD4 + FoxP3 - helper T cells in the irradiated tumors, respectively. (c) The corresponding data of the unirradiated tumors. ${ }^{*} p<0.05$.

\section{Discussion}

Osteosarcoma has long been considered as X-ray- and immunotherapy-resistant [26,44]. However, our former study revealed that dual immune checkpoint blockade of P1 and C4 and concurrent use of $10 \mathrm{~Gy} \mathrm{X}$-ray irradiation successfully enhanced systemic antitumor immunity, which lead to a significant abscopal effect and prolonged survival in a murine osteosarcoma model [31]. However, the therapeutic response of osteosarcoma to single immune checkpoint blockade combined with various radiation delivery regimens remained unclear. To the best of our knowledge, this is the first evidence that revealed the necessity of radiation dose escalation regardless of the number of fractionations to enhance systemic antitumor efficacy, especially in combination with $\mathrm{C} 4$ for osteosarcoma. Although three-four cycles of anti-CTLA-4 antibody are administered in clinical trials of sarcoma and other tumor patients [45-47], we administered three cycles of anti-CTLA-4 antibody in 
the present study based on previous preclinical reports [22,35,47], allowing us to compare our data with other reports. Under this preclinical setting, we found that radiation dose escalation was crucial to induce sufficient systemic anticancer efficacy, even with the use of single checkpoint blockade of $\mathrm{C} 4$, and regardless of single-fraction or hypofraction delivery. However, an intermediate radiation dose (i.e., $10 \mathrm{~Gy}, 4.5 \mathrm{~Gy} \times 3 \mathrm{fx}$, and $2 \mathrm{~Gy} \times 8 \mathrm{fx}$ ) failed to enhance the antitumor efficacy in $\mathrm{C} 4$ therapy. Recently, Dewan MZ et al. and Vanpouille-Box et al. demonstrated that high-dose hypofractionated RT, but not the single delivery of 8 Gy nor 20 Gy, evoked a sufficient systemic antitumor effect in combination with C4 in murine mammary and colon carcinoma models [22,35]. Similar to their findings, our results confirmed that the single delivery of $10 \mathrm{~Gy}$ irradiation did not enhance antitumor efficacy both in IR and UnIR tumors, resulting in comparable survival with monotherapy of C4.

To find the optimal radiation dose to induce the type-I interferon pathway, we first conducted in vitro experiments prior to conducting in vivo experiments based on a previous report [35]. The type-I interferon pathway plays an important role in adaptive immunity to external stimuli such as viral infections and radiation [48,49]. Cytoplasmic dsDNA activates the cGAS/STING/IRF3 pathway leading to secretion of type-I interferons such as IFN- $\beta[38,50]$. Increasing evidence has suggested that dsDNA accumulates in the cytosol after irradiation [35,51-54]. Indeed, Vanpouille-Box et al. demonstrated that accumulation of dsDNA, upregulation of Ifnb1, and release of IFN- $\beta$ were only induced following high-dose hypofractionated irradiation but not low-dose nor high-dose irradiation in a single fraction [35]. In contrast, our data revealed that cytoplasmic dsDNA accumulation dramatically increased not only at hypofractionation (i.e., $8 \mathrm{~Gy} \times 3 \mathrm{fx}$ ) but also at high dose (i.e., $16 \mathrm{~Gy}$ ). Accordingly, the expression of its downstream signal, phospho-IRF3, which is one of the transcription factors of Ifnb1, was activated by a high dose in either a single fraction or hypofractionation. Moreover, our gene expression analysis on Ifnb1 also showed a striking correlation with the change in dsDNA expression. However, secretion of IFN- $\beta$ did not correlate with the accumulation of dsDNA or IFN- $\beta$ gene expression. Similar to the finding by Vanpouille-Box et al. [35], our data also revealed that 8 Gy $\times 3$ fx significantly promoted the release of IFN- $\beta 24$ h after irradiation, whereas 10 Gy did not. Unlike the report of Vanpouille-Box et al, our data revealed that high-dose delivery in a single fraction still induced IFN- $\beta$ secretion at a later time point than in hypofractionated irradiation. Moreover, the amount of secreted IFN- $\beta$ was even greater at a high dose (i.e., 16 Gy) and extremely high dose (i.e., $30 \mathrm{~Gy}$ ) in a single fraction $48 \mathrm{~h}$ after irradiation. These results suggest that high-dose irradiation is crucial for triggering the immune response, regardless of fractionation for osteosarcoma. In support of this, our data revealed that both $8 \mathrm{~Gy} \times 3 \mathrm{fx}$ and $16 \mathrm{~Gy}$ of irradiation provided equally robust tumor growth delay in both IR and UnIR sites in combination with C4 in vivo. Consistently with this finding, the overall survival was significantly extended, again suggesting that not only hypofractionation but also a single fraction with a high dose are necessary to induce local and systemic control.

The LM8 cells/C3H mice model easily induce lung and liver metastasis $[31,55,56]$. Our study showed that the majority of deaths in treated or untreated mice were due to distant metastasis, which was confirmed by necropsy, clearly indicating that overall survival reflects the likelihood of distant metastasis. Thus, tumor growth delay in the abscopal tumor with the prolonged overall survival in the C4 with high-dose radiation group reflects the distant metastasis inhibition to a large extent.

Furthermore, we found that a combination of C4 with high-dose RT did not induce severe systemic adverse events, including apparent body weight loss, apparent slimming, and prostration, after the treatments except for those mice just before death due to metastatic burden. In contrast, the high-dose RT in our study induced a Grade I local skin reaction based on the criteria of radiation-induced skin reaction [42]. However, the skin reaction recovered within nine days, suggesting that $C 4$ with high-dose radiation is a tolerable treatment option in this model.

To understand how the optimal dose of irradiation affects the immune cell distribution in IR and UnIR tumors, we further investigated the components of the tumor microenvironment. Tregs were downregulated in both IR and UnIR lesions by high-dose irradiation at $8 \mathrm{~Gy} \times 3 \mathrm{fx}$ and $16 \mathrm{~Gy}$. In contrast, 10 Gy irradiation decreased Tregs only in IR tumors, but only a slight decrease was observed in UnIR 
tumors at this dose level. Previous reports demonstrated that naïve T cells differentiate into type-17 helper T cells when TGF- $\beta$ and IL- 6 coexist but differentiate into Tregs in the presence of TGF- $\beta$ and absence of IL-6 [57]. Yagi et al. reported that IL-6 secretion was increased by 16 Gy in a single fraction (delivered to both the hind limbs of mice) [58]; hence, Tregs may be reduced after high-dose radiation not only in IR tumors but also in UnIR tumors. Taken together, regardless of fractionation, high-dose radiation, but not low and intermediate doses, facilitates a favorable immune microenvironment. Thus, irradiation at $8 \mathrm{~Gy} \times 3 \mathrm{fx}$ and $16 \mathrm{~Gy}$ combined with C4 could enhance the systemic efficacy of C4, leading to sufficient suppression of both IR and UnIR tumors and extension of survival in mice with osteosarcoma.

Overall, our data revealed that high-dose local irradiation can almost eradicate local tumors and is a crucial factor in osteosarcoma in mice. Further dose escalation may provide better local control and freedom from distant metastasis. However, even the use of high-precision radiation therapy techniques limits the dose escalation because of possible normal tissue toxicities. Recently, our group reported that carbon ion irradiation with dual immune checkpoint blockade enhanced the antitumor effect in both local and distant sites in vivo [56]. Carbon ion beams have a superior dose distribution that can achieve a highly focused dose to targets with rapid dose fall-off nearby normal tissues [59]. Therefore, dose escalation using carbon ion beams with C4 may provide a better antitumor immune response with more decreased toxicity than photon beams in carbon ion irradiation. Further studies are necessary to achieve much better control of local and distant sites for osteosarcoma. In addition, sarcoma inoculated into bone reflects the effect of the microenvironment on the immune response, including the type-I interferon pathway, which is a more clinically relevant approach. Further studies are necessary to investigate the efficacy and underlying mechanisms of $\mathrm{C} 4$ with radiation for sarcoma under bone microenvironments.

\section{Materials and Methods}

\subsection{Ethics Statement}

All animal experiments were approved by Osaka University Institutional Animal Care and Use Committee on 2/14/2018 (Approve number; 30-014-005) and performed using the minimum-distress procedure. Mice were basically observed daily and were humanely sacrificed with $\mathrm{CO}_{2}$ or sevoflurane inhalation when they met the following humane endpoints: dysfunction of walking, rotating, and longest tumor diameter exceeding $20 \mathrm{~mm}$.

\subsection{Cells and Reagents}

The highly metastatic murine osteosarcoma cell line LM8 was purchased from RIKEN (Saitama, Japan). Cells were cultured in Dulbecco's modified Eagle's medium containing $10 \%$ fetal bovine serum, $1 \%$ penicillin/streptomycin, and L-glutamine, at $37{ }^{\circ} \mathrm{C}$ in an incubator at $5 \% \mathrm{CO}_{2}$ atmosphere.

\subsection{In Vivo Experiment}

Six to seven-week-old C3H mice were purchased from Nihon-Clea (Tokyo, Japan) and were maintained under specific pathogen-free conditions in Osaka University. The mice were subcutaneously inoculated with $3 \times 10^{5}$ LM8 cells into the hind of both thighs (Figure 1a). To evaluate the efficacy of monotherapy with the anti-CTLA-4 antibody (clone: 9H10, Bio $\times$ Cell, Lebanon, NH, USA), mice were assigned to No TX (received no treatment) or C4 only (150 $\mathrm{gg} \times 3$ times of C4 administration) groups as shown in Figure $1 b$. To evaluate the efficacy of combination therapy of $C 4$ with concurrent use of $X$-ray at $10 \mathrm{~Gy}$ or its equivalent dose in fractionation, mice were randomly assigned to the following four groups: C4 only, C4/Conc-10 Gy (C4 and concurrent use of X-ray irradiation at $10 \mathrm{~Gy}$ ), C4/Conc-4.5 Gy $\times 3 \mathrm{fx}$ (combinatorial therapy of $\mathrm{C} 4$ and hypofractionated radiation), or C4/Conc-2 Gy $\times 8 \mathrm{fx}$ (clinically daily fractionated RT with C4 administration) (Figure 2a). To investigate the benefit of dose escalation for the 
local and abscopal effect, mice were randomly assigned to three groups as follows: C4 only, C4/Conc-16 Gy, and C4/Conc-8 Gy $\times 3 \mathrm{fx}$ (Figure 4a). The single-fraction dose equivalent to the multiple fractions was determined based on a linear-quadratic model [36,37].

C4 at $150 \mu \mathrm{g} / \mathrm{mouse} /$ day was intraperitoneally administered on days 0,3 , and 6 after the tumor volume reached $\geq 14 \mathrm{~mm}^{3}$. One side of the tumor was irradiated using an orthovoltage $X$-ray irradiator, RF-350 (Rigaku Denki, Tokyo, Japan), under the condition of $180 \mathrm{kV}, 15 \mathrm{~mA}$. The rest of the mouse's body was shielded with more than $4 \mathrm{~mm}$ lead blocks. During irradiation, mice were anesthetized with $40 \mathrm{mg} / \mathrm{kg} /$ day of Pentobarbital Na diluted in PBS to fix in an in-house jig.

Tumor volume was measured at least every 3 days and calculated with the following formula: (longest diameter) $2 \times$ (shortest diameter) $\times \pi / 6$ and binned 3 days for analysis.

\subsection{In Vitro Irradiation}

Cells were irradiated with a Gammacell 40 Exactor (Best Theratronics Ltd., Ottawa, ON, Canada), and irradiation was performed $12-18 \mathrm{~h}$ after seeding.

\subsection{RNA Preparation and Quantitative RT-PCR}

RNA samples obtained from cultured LM8 cells $24 \mathrm{~h}$ after irradiation according to the protocol of RNeasy Mini kit (QIAGEN, Hilden, Germany) were reverse-transcribed to cDNA as described previously [31]. Quantitative polymerase chain reaction with reverse transcription (qRT-PCR) was performed with PowerSYBR Green PCR Master Mix (Thermo Fisher Scientific, Waltham, MA, USA). The reactions were run using the ViiA7 Real-Time PCR System (Thermo Fisher Scientific) with an annealing temperature of $60^{\circ} \mathrm{C}$. The gene-specific primer sequence of Ifnb1 is as follows:

\section{Ifnb1 Fw 5'-AAGAGTTACACTGCCTTTGCCATC-3' \\ Ifnb1 Rv 5'-CACTGTCTGCTGGTGGAGTTCATC-3'}

where the GenBank accession number is NM_010510 and the loci of Fw and Rv primers are from the 225th to 248th and from the 336th to 359th of the published base sequences of the mRNA, respectively.

GAPDH was used as the reference gene, with the gene-specific primer sequence of Ifnb1 as follows:

\section{Gapdh Fw 5'-ACCACAGTCCATGCCATCAC-3' \\ Gapdh Rv 5'-CACCACCCTGTTGCTGTAGCC-3'}

where the GenBank accession number is NM_001289726 and the loci of Fw and Rv primers are from the 612th to 631st and from the 1041st to 1061st of the published base sequence of the mRNA, respectively.

The $2^{-\Delta \Delta C t}$ method was used to determine the relative fold expression change of $I f b 1$ according to the following formula [60].

$$
\Delta \Delta \mathrm{Ct}=\Delta \mathrm{Ct} \text { (irradiated sample) }-\Delta \mathrm{Ct} \text { (0 Gy sample) }
$$

where $\Delta \mathrm{Ct}$ is calculated using the following formula.

$$
\Delta \mathrm{Ct}=\mathrm{Ct}(\mathrm{Ifnb1})-\mathrm{Ct}(\mathrm{Gapdh}) .
$$

\subsection{Flow Cytometry}

To analyze the tumor immune microenvironment after irradiation, mice untreated or treated by a single fraction of $10 \mathrm{~Gy}, 16 \mathrm{~Gy}$, or $8 \mathrm{~Gy} \times 3 \mathrm{fx}$ were sacrificed 3 days after the last delivery of irradiation. A single cell suspension was prepared as previously described [31,56,61]. Briefly, harvested tissue was dissociated with Collagenase IV (Sigma Aldrich, Tokyo, Japan) and DNAse II (Sigma Aldrich). After blocking Fc receptors with anti-CD16/32 antibody (clone nr. 93, BioLegend, San Diego, CA, USA), 
cells were incubated with anti-CD4-APC antibody (RM4-5, eBioscience) on ice for $30 \mathrm{~min}$ at a ratio of 1:80 with FACS buffer (PBS containing 10\% FBS and $0.5 \mathrm{mM}$ EDTA). Then, cells were fixed, permeabilized, and incubated with anti-Foxp3-PE antibody (FJK-16s, eBioscience) on ice for $30 \mathrm{~min}$ at a ratio of 1:80. Fixation and permeabilization were conducted using a Foxp3 staining buffer kit (eBioscience). After washing twice with permeabilization buffer followed by washing once with FACS buffer, cells were analyzed with a FACS verse flow cytometer (Beckton Dickinson, Franklin Lakes, NJ, USA). Data were analyzed using Flow Jo ver. 10 (Tommy Digital Biology, Tokyo, Japan).

\subsection{Quantification of Cytosolic Double-Stranded DNA}

Irradiated cells in the cytoplasm were isolated using NE-PER ${ }^{\mathrm{TM}}$ Nuclear and Cytoplasmic Extraction Reagents (Thermo Fisher Scientific). Double-stranded DNA (dsDNA) in the cytoplasm of $1 \times 10^{6}$ live LM8 cells was quantified with the SpectraMax ${ }^{\circledR}$ Quant ${ }^{\mathrm{TM}}$ AccuClear Nano dsDNA Assay Explorer kit (Molecular devices, San Jose, CA, USA) $24 \mathrm{~h}$ after the last delivery of irradiation. The samples were analyzed by Varioskan (Thermo Fisher Scientific, Waltham, MA, USA).

\subsection{Measurement of IFN- $\beta$ Secretion}

Cell-free supernatants were collected 24 or $48 \mathrm{~h}$ after the last irradiation. A mouse IFN- $\beta$ high-sensitivity ELISA kit (PBL Assay Science, Piscataway, NJ, USA) was used to quantify secreted IFN- $\beta$. The sensitivity is $0.94 \mathrm{pg} / \mathrm{mL}$ according to the manufacturer's specification. All procedures were performed according to the manufacturer's manual, and the concentration measurement was performed with Varioskan (Thermo Fisher Scientific). The concentration $[\mathrm{pg} / \mathrm{mL}]$ per $10^{5}$ live cells was analyzed according to a previous study [35].

\subsection{Western Blotting}

LM8 cells were lysed in PierceTM RIPA buffer (Thermo Fisher Scientific) supplemented with $1 \%$ 100 $\times$ Protease/Phosphatase inhibitor (Thermo Fisher Scientific) $24 \mathrm{~h}$ after the last irradiation. Whole cell extracts were centrifuged at $14,000 \mathrm{rpm}$ for $15 \mathrm{~min}$ at $4{ }^{\circ} \mathrm{C}$. The protein concentration of each sample was determined with a Pierce ${ }^{\mathrm{TM}}$ BCA Protein Assay Kit (Thermo Fisher Scientific) by measuring the absorption using Varioskan (Thermo Fisher Scientific) according to the manufacturer's instructions. For SDS-PAGE, samples were run using $10 \%$ unstained precast gel (Bio-Rad, Hercules, CA, USA) under the condition of $70 \mathrm{kV}$ for $10 \mathrm{~min}$ followed by at $100 \mathrm{kV}$ for $1 \mathrm{~h}$. The wet tank method was used to transfer proteins to a PVDF membrane under the condition of $100 \mathrm{kV}$ for $1 \mathrm{~h}$. The membrane was blocked with blocking buffer (TBS-T containing 5\% BSA or non-fat milk powder) for $1 \mathrm{~h}$ at room temperature before reacting with cGAS (clone nr. D3080, Cell Signaling Technologies, Danvers, MA, USA), STING (D1V5L, Cell Signaling Technologies), IRF3 (D83B9, Cell Signaling Technologies), and phospho-IRF3 (S396) (D601M, Cell Signaling Technologies) specific primary antibodies overnight at $4{ }^{\circ} \mathrm{C}$ at a ratio of 1:1250 with blocking buffer. The membrane was incubated with horseradish peroxidase-conjugated secondary antibody (Cell Signaling Technologies) for $1 \mathrm{~h}$ at room temperature at a ratio of 1:3000 with blocking buffer. SuperSignal ${ }^{\mathrm{TM}}$ West Pico PLUS Chemiluminescent Substrate (Thermo Fisher Scientific) was used for chemiluminescence, and specific bands were visualized utilizing the ChemiDoc + XRS or ChemiDoC Touch imaging systems (Bio-Rad, Hercules, CA, USA). Densitometric quantification of the Western blot signals was performed using Image (National Institutes of Health, Bethesda, MD, USA), an open source program for image processing. The region of interest was set on the bands of the specific protein, followed by a measurement of the signal density in the area of each blot. Each calculated value in the specific sample was normalized by the corresponding value of the loading control ( $\beta$-actin).

\subsection{Statistics}

For the tumor volume comparison, the Mann-Whitney $U$ test or Steel test were performed for a one-on-one comparison or multiple comparisons, respectively. Overall survival was analyzed by the 
Kaplan-Meier method, and statistical significance was calculated by a log-rank test. Tumor volume graphs are presented as mean \pm SEM (standard error of the mean).

The chi-squared test was used for the comparison of the responders and the acute skin reaction between the high- and intermediate-dose regimens.

Dunnet's multiple comparison test was conducted for the comparison of the flow cytometry results between the $0,10,16 \mathrm{~Gy}$, and $8 \mathrm{~Gy} \times 3 \mathrm{fx}$ groups. Tukey-Kramer's honestly significant difference test was used to compare the concentration of IFN- $\beta$ in the supernatant between $10 \mathrm{~Gy}, 16 \mathrm{~Gy}$, and $8 \mathrm{~Gy} \times 3 \mathrm{fx}$ $48 \mathrm{~h}$ after irradiation, and dsDNA in cytoplasm and fold expression change of the IFN-b gene between the $0 \mathrm{~Gy}, 10 \mathrm{~Gy}, 16 \mathrm{~Gy}$, and $8 \mathrm{~Gy} \times 3$ fx groups. A two-tailed Student's t-test was used to compare the IFN- $\beta$ concentration between $8 \mathrm{~Gy} \times 3 \mathrm{f} \times 24 \mathrm{~h}$ after irradiation and $8 \mathrm{~Gy} \times 3 \mathrm{f} \times 48 \mathrm{~h}$ after irradiation. The graphs of flow cytometry and all in vitro experiments are presented as mean \pm standard deviation.

\section{Conclusions}

Our data demonstrated that high-dose irradiation strongly activated the type-I IFN pathway and induced IFN- $\beta$ secretion. Radiation dose escalation that almost eradicates tumors was crucial in C4 therapy to enhance the antitumor response in both local and distant tumors, as well as for prolonged overall survival regardless of fractionation in osteosarcoma. These data provide rationale for the development of new therapeutic strategies for patients with osteosarcoma. Further dose escalation by hypofractionated or a single fraction of radiation delivery may provide greater improvement of the local and distant tumor controls. However, even the use of high-precision radiation therapy techniques using X-ray limits dose escalation because of possible normal tissue toxicities. Owing to the superior physical and biological characteristics of carbon ion beams, dose escalation using carbon ion beams with C4 may provide a better antitumor immune response than photon beams. Further studies using carbon ion beams with immune checkpoint blockade are necessary to achieve much better control of local and distant tumors for osteosarcoma.

Supplementary Materials: The following are available online at http://www.mdpi.com/2072-6694/12/6/1546/s1, Figure S1: Pie charts showing the ratio between complete and partial response (CR + PR) and stable and progressive disease (SD+PD) of the abscopal tumor between $\mathrm{C} 4$ only and $\mathrm{C} 4$ with intermediate dose $(10 \mathrm{~Gy}, 4.5 \mathrm{~Gy} \times 3 \mathrm{fx}$ and $2 \mathrm{~Gy} \times 8 \mathrm{fx}$ ) groups, Figure S2: Concentration of IFN- $\beta$ in the cell culture supernatant 24 and $48 \mathrm{~h}$ after the final delivery of irradiation at $0 \mathrm{~Gy}, 2 \mathrm{~Gy}$, and $30 \mathrm{~Gy}$, Figure S3: Untrimed Western blot data. Figure S4: Comparison of tumor volumes between sequential and concurrent combinations of high-dose hypofractionated irradiation with C4 therapy.

Author Contributions: Conceptualization, Y.T. and K.O.; data curation, W.T., Y.T., and S.K.; formal analysis, W.T. and Y.T.; funding acquisition, Y.T. and K.O.; investigation, W.T., Y.T., and S.K.; methodology, W.T., Y.T., K.T., K.M., Y.S., F.I., M.K., and K.O.; project administration, Y.T. and K.O.; resources, K.T.; supervision, Y.T., Y.S., F.I., M.K., and K.O.; validation, Y.T.; writing-original draft, W.T.; writing—review and editing, Y.T., K.T., K.M., S.K., Y.S., F.I., M.K., and K.O. All authors have read and agree to the published version of the manuscript.

Funding: This work was supported by a grant in aid from the Japanese Society of Promotion of Sciences (Kiban C: 19K08151, Kiban C: 16K07173, Kiban B 18H02767). This study was also supported by a Research Grant of the Princess Takamatsu Cancer Research Fund (16-24805).

Acknowledgments: This study was supported by Center for Medical Research and Education, Graduated School of Medicine, Osaka University. We thank Y. Ibuki, J. Yamamoto, and J. Shimoda for their technical supports.

Conflicts of Interest: The authors declare no conflict of interest.

\section{References}

1. Dagoglu, N.; Karaman, S.; Caglar, H.B.; Oral, E.N. Abscopal Effect of Radiotherapy in the Immunotherapy Era: Systematic Review of Reported Cases. Cureus 2019, 11, e4103. [CrossRef] [PubMed]

2. Bonilla, C.E.; Esguerra, J.; Mendoza Díaz, S.; Álvarez, A.; Morales, R.L. Abscopal Effect After Palliative Radiotherapy in a Patient with a Gastric Adenocarcinoma Disseminated to Retroperitoneal Space: Case Report from a Latin American Reference Center and Review of the Literature. Cureus 2019, 11, e6235. [CrossRef] [PubMed] 
3. Bruton Joe, M.; Truong, P.T. Abscopal Effect after Palliative Radiation Therapy for Metastatic Adenocarcinoma of the Esophagus. Cureus 2018, 10, e3089. [CrossRef] [PubMed]

4. Shiraishi, K. Abcopal effect of radiation therapy: Current concepts and future applications. In Modern Practices in Radiation Therapy; Natanasabapathi, G., Ed.; InTech Europe: Rijeka, Croatia, 2012; pp. 275-288.

5. Formenti, S.C.; Demaria, S. Systemic effects of local radiotherapy. Lancet Oncol. 2009, 10, 718-726. [CrossRef]

6. Lee, Y.; Auh, S.L.; Wang, Y.; Burnette, B.; Wang, Y.; Meng, Y.; Beckett, M.; Sharma, R.; Chin, R.; Tu, T.; et al. Therapeutic effects of ablative radiation on local tumor require CD8+ T cells: Changing strategies for cancer treatment. Blood 2009, 114, 589-595. [CrossRef] [PubMed]

7. Salama, A.K.; Postow, M.A.; Salama, J.K. Irradiation and immunotherapy: From concept to the clinic. Cancer 2016, 122, 1659-1671. [CrossRef]

8. El Chediak, A.; Shamseddine, A.; Bodgi, L.; Obeid, J.P.; Geara, F.; Zeidan, Y.H. Optimizing tumor immune response through combination of radiation and immunotherapy. Med. Oncol. 2017, 34, 165. [CrossRef]

9. Rodríguez-Ruiz, M.E.; Vanpouille-Box, C.; Melero, I.; Formenti, S.C.; Demaria, S. Immunological mechanisms responsible for radiation-induced abscopal effect. Trends Immunol. 2018, 39, 644-655. [CrossRef]

10. Reynders, K.; Illidge, T.; Siva, S.; Chang, J.Y.; De Ruysscher, D. The abscopal effect of local radiotherapy: Using immunotherapy to make a rare event clinically relevant. Cancer Treat. Rev. 2015, 41, 503-510. [CrossRef]

11. Mellman, I.; Coukos, G.; Dranoff, G. Cancer immunotherapy comes of age. Nature 2011, 480, 480-489. [CrossRef]

12. Iwai, Y.; Ishida, M.; Tanaka, Y.; Okazaki, T.; Honjo, T.; Minato, N. Involvement of PD-L1 on tumor cells in the escape from host immune system and tumor immunotherapy by PD-L1 blockade. Proc. Natl. Acad. Sci. USA 2002, 99, 12293-12297. [CrossRef]

13. Leach, D.R.; Krummel, M.F.; Allison, J.P. Enhancement of antitumor immunity by CTLA-4 blockade. Science 1996, 271, 1734-1736. [CrossRef]

14. Hirano, F.; Kaneko, K.; Tamura, H.; Dong, H.; Wang, S.; Ichikawa, M.; Rietz, C.; Flies, D.B.; Lau, J.S.; Zhu, G.; et al. Blockade of B7-H1 and PD-1 by monoclonal antibodies potentiates cancer therapeutic immunity. Cancer Res. 2005, 65, 1089-1096. [PubMed]

15. Verma, A.; Mathur, R.; Farooque, A.; Kaul, V.; Gupta, S.; Dwarakanath, B.S. T-Regulatory Cells in Tumor Progression and Therapy. Cancer Manag. Res. 2019, 11, 10731-10747. [CrossRef] [PubMed]

16. Furue, M.; Ito, T.; Wada, N.; Wada, M.; Kadono, T.; Uchi, H. Melanoma and Immune Checkpoint Inhibitors. Curr. Oncol. Rep. 2018, 20, 29. [CrossRef] [PubMed]

17. Gong, J.; Le, T.Q.; Massarelli, E.; Hendifar, A.E.; Tuli, R. Radiation therapy and PD-1/PD-L1 blockade: The clinical development of an evolving anticancer combination. J. Immunother. Cancer 2018, 6, 46. [CrossRef] [PubMed]

18. Deng, L.; Liang, H.; Burnette, B.; Beckett, M.; Darga, T.; Weichselbaum, R.R.; Fu, Y.X. Irradiation and anti-PD-L1 treatment synergistically promote antitumor immunity in mice. J. Clin. Investig. 2014, 124, 687-695. [CrossRef]

19. Dovedi, S.J.; Cheadle, E.J.; Popple, A.L.; Poon, E.; Morrow, M.; Stewart, R.; Yusko, E.C.; Sanders, C.M.; Vignali, M.; Emerson, R.O.; et al. Fractionated Radiation Therapy Stimulates Antitumor Immunity Mediated by Both Resident and Infiltrating Polyclonal T-cell Populations when Combined with PD-1 Blockade. Clin. Cancer Res. 2017, 23, 5514-5526. [CrossRef]

20. Dovedi, S.J.; Adlard, A.L.; Lipowska-Bhalla, G.; McKenna, C.; Jones, S.; Cheadle, E.J.; Stratford, I.J.; Poon, E.; Morrow, M.; Stewart, R.; et al. Acquired resistance to fractionated radiotherapy can be overcome by concurrent PD-L1 blockade. Cancer Res. 2014, 74, 5458-5468. [CrossRef]

21. Demaria, S.; Kawashima, N.; Yang, A.M.; Devitt, M.L.; Babb, J.S.; Allison, J.P.; Formenti, S.C. Immune-mediated inhibition of metastases after treatment with local radiation and CTLA-4 blockade in a mouse model of breast cancer. Clin. Cancer Res. 2005, 11 Pt 1, 728-734.

22. Dewan, M.Z.; Galloway, A.E.; Kawashima, N.; Dewyngaert, J.K.; Babb, J.S.; Formenti, S.C.; Demaria, S. Fractionated but not single-dose radiotherapy induces an immune-mediated abscopal effect when combined with anti-CTLA-4 antibody. Clin. Cancer Res. 2009, 15, 5379-5388. [CrossRef] [PubMed]

23. Yoshimoto, Y.; Suzuki, Y.; Mimura, K.; Ando, K.; Oike, T.; Sato, H.; Okonogi, N.; Maruyama, T.; Izawa, S.; Noda, S.E.; et al. Radiotherapy-induced anti-tumor immunity contributes to the therapeutic efficacy of irradiation and can be augmented by CTLA-4 blockade in a mouse model. PLoS ONE 2014, 9, e92572. [CrossRef] [PubMed] 
24. Neifeld, J.P.; Michaelis, L.L.; Doppman, J.L. Suspected pulmonary metastases: Correlation of chest x-ray, whole lung tomograms, and operative findings. Cancer 1977, 39, 383-387. [CrossRef]

25. Marina, N.M.; Pratt, C.B.; Rao, B.N.; Shema, S.J.; Meyer, W.H. Improved prognosis of children with osteosarcoma metastatic to the lung(s) at the time of diagnosis. Cancer 1992, 70, 2722-2727. [CrossRef]

26. Marina, N.; Gebhardt, M.; Teot, L.; Gorlick, R. Biology and therapeutic advances for pediatric osteosarcoma. Oncologist 2004, 9, 422-441. [CrossRef]

27. Pratt, C.B.; Shanks, E.C. Doxorubicin in treatment of malignant solid tumors in children. Am. J. Dis. Child. 1974, 127, 534-536. [CrossRef]

28. Pratt, C.B.; Roberts, D.; Shanks, E.C.; Warmath, E.L. Clinical trials and pharmacokinetics of intermittent high-dose methotrexate-“leucovorin rescue" for children with malignant tumors. Cancer Res. 1974, 34, 3326-3331.

29. dos Santos Cavalcanti, A.; Meohas, W.; de Oliveira Ribeiro, G.; de Sa Lopes, A.C.; Gholamin, S.; Razavi, M.; Brunswick, T.H.; Avan, A.; Guimaraes, J.A.; Duarte, M.E.; et al. Patient-derived osteosarcoma cells are resistant to methotrexate. PLoS ONE 2017, 12, e0184891. [CrossRef]

30. Liu, T.; Li, Z.; Zhang, Q.; Bernstein, K.D.; Lozano-Calderon, S.; Choy, E.; Hornicek, F.J.; Duan, Z. Targeting ABCB1 (MDR1) in multi-drug resistant osteosarcoma cells using the CRISPR-Cas9 system to reverse drug resistance. Oncotarget 2016, 7, 83502-83513. [CrossRef]

31. Takahashi, Y.; Yasui, T.; Tamari, K.; Minami, K.; Otani, K.; Isohashi, F.; Seo, Y.; Kambe, R.; Koizumi, M.; Ogawa, K. Radiation enhanced the local and distant anti-tumor efficacy in dual immune checkpoint blockade therapy in osteosarcoma. PLoS ONE 2017, 12, e0189697. [CrossRef]

32. Gelao, L.; Criscitiello, C.; Esposito, A.; Goldhirsch, A.; Curigliano, G. Immune checkpoint blockade in cancer treatment: A double-edged sword cross-targeting the host as an "innocent bystander". Toxins 2014, 6, 914-933. [CrossRef] [PubMed]

33. Yun, S.; Vincelette, N.D.; Green, M.R.; Wahner Hendrickson, A.E.; Abraham, I. Targeting immune checkpoints in unresectable metastatic cutaneous melanoma: A systematic review and meta-analysis of anti-CTLA-4 and anti-PD-1 agents trials. Cancer Med. 2016, 5, 1481-1491. [CrossRef] [PubMed]

34. Mohamad, O.; Diaz de Leon, A.; Schroeder, S.; Leiker, A.; Christie, A.; Zhang-Velten, E.; Trivedi, L.; Khan, S.; Desai, N.B.; Laine, A.; et al. Safety and efficacy of concurrent immune checkpoint inhibitors and hypofractionated body radiotherapy. Oncoimmunology 2018, 7, e1440168. [CrossRef] [PubMed]

35. Vanpouille-Box, C.; Alard, A.; Aryankalayil, M.J.; Sarfraz, Y.; Diamond, J.M.; Schneider, R.J.; Inghirami, G.; Coleman, C.N.; Formenti, S.C.; Demaria, S. DNA exonuclease Trex1 regulates radiotherapy-induced tumour immunogenicity. Nat. Commun. 2017, 8, 15618. [CrossRef]

36. Brenner, D.J.; Hall, E.J. The origins and basis of the linear-quadratic model. Int. J. Radiat. Oncol. Biol. Phys. 1992, 23, 252-253. [CrossRef]

37. Lee, S.P.; Leu, M.Y.; Smathers, J.B.; McBride, W.H.; Parker, R.G.; Withers, H.R. Biologically effective dose distribution based on the linear quadratic model and its clinical relevance. Int. J. Radiat. Oncol. Biol. Phys. 1995, 33, 375-389. [CrossRef]

38. Li, T.; Chen, Z.J. The cGAS-cGAMP-STING pathway connects DNA damage to inflammation, senescence, and cancer. J. Exp. Med. 2018, 215, 1287-1299. [CrossRef]

39. Cai, X.; Chiu, Y.H.; Chen, Z.J. The cGAS-cGAMP-STING pathway of cytosolic DNA sensing and signaling. Mol. Cell 2014, 54, 289-296. [CrossRef]

40. Fuertes, M.B.; Kacha, A.K.; Kline, J.; Woo, S.R.; Kranz, D.M.; Murphy, K.M.; Gajewski, T.F. Host type I IFN signals are required for antitumor CD8+ T cell responses through CD8\{alpha\}+ dendritic cells. J. Exp. Med. 2011, 208, 2005-2016. [CrossRef]

41. Jacquelot, N.; Yamazaki, T.; Roberti, M.P.; Duong, C.P.; Andrews, M.C.; Verlingue, L.; Ferrere, G.; Becharef, S.; Vétizou, M.; Daillère, R.; et al. Sustained Type I interferon signaling as a mechanism of resistance to PD-1 blockade. Cell Res. 2019, 29, 846-861. [CrossRef]

42. Wei, J.; Meng, L.; Hou, X.; Qu, C.; Wang, B.; Xin, Y.; Jiang, X. Radiation-induced skin reactions: Mechanism and treatment. Cancer Manag. Res. 2018, 11, 167-177. [CrossRef] [PubMed]

43. Hori, S.; Nomura, R.; Sakaguchi, S. Control of regulatory T cell development by transcription factor Fop3. Science 2003, 299, 1057-1061. [CrossRef] [PubMed]

44. Wedekind, M.F.; Wagner, L.M.; Cripe, T.P. Immunotherapy for osteosarcoma: Where do we go from here? Pediatr. Blood Cancer 2018, 65, e27227. [CrossRef] [PubMed] 
45. Maki, R.G.; Jungbluth, A.A.; Gnjatic, S.; Schwartz, G.K.; D'Adamo, D.R.; Keohan, M.L.; Wagner, M.J.; Scheu, K.; Chiu, R.; Ritter, E.; et al. A Pilot Study of Anti-CTLA4 Antibody Ipilimumab in Patients with Synovial Sarcoma. Sarcoma 2013, 2013, 168145. [CrossRef] [PubMed]

46. Thanindratarn, P.; Dean, D.C.; Nelson, S.D.; Hornicek, F.J.; Duan, Z. Advances in immune checkpoint inhibitors for bone sarcoma therapy. J. Bone Oncol. 2019, 15, 100221. [CrossRef]

47. Twyman-Saint Victor, C.; Rech, A.J.; Maity, A.; Rengan, R.; Pauken, K.E.; Stelekati, E.; Benci, J.L.; Xu, B.; Dada, H.; Odorizzi, P.M.; et al. Radiation and dual checkpoint blockade activate non-redundant immune mechanisms in cancer. Nature 2015, 520,373-377. [CrossRef]

48. Burnette, B.C.; Liang, H.; Lee, Y.; Chlewicki, L.; Khodarev, N.N.; Weichselbaum, R.R.; Fu, Y.X.; Auh, S.L. The efficacy of radiotherapy relies upon induction of type i interferon-dependent innate and adaptive immunity. Cancer Res. 2011, 71, 2488-2496. [CrossRef]

49. Teijaro, J.R. Type I interferons in viral control and immune regulation. Curr. Opin. Virol. 2016, 16, 31-40. [CrossRef]

50. Abe, T. Innate immune DNA sensing pathways. Uirusu 2014, 64, 83-94. [CrossRef]

51. Kondo, T.; Kobayashi, J.; Saitoh, T.; Maruyama, K.; Ishii, K.J.; Barber, G.N.; Komatsu, K.; Akira, S.; Kawai, T. DNA damage sensor MRE11 recognizes cytosolic double-stranded DNA and induces type I interferon by regulating STING trafficking. Proc. Natl. Acad. Sci. USA 2013, 110, 2969-2974. [CrossRef]

52. Yang, H.; Wang, H.; Ren, J.; Chen, Q.; Chen, Z.J. cGAS is essential for cellular senescence. Proc. Natl. Acad. Sci. USA 2017, 114, E4612-E4620. [CrossRef] [PubMed]

53. Diamond, J.M.; Vanpouille-Box, C.; Spada, S.; Rudqvist, N.P.; Chapman, J.; Ueberheide, B.; Pilones, K.A.; Sarfraz, Y.; Formenti, S.C.; Demaria, S. Exosomes Shuttle TREX1-Sensitive IFN-Stimulatory dsDNA from Irradiated Cancer Cells to DCs. Cancer Immunol. Res. 2018, 6, 910-920. [CrossRef] [PubMed]

54. Liu, Y.P.; Zeng, L.; Tian, A.; Bomkamp, A.; Rivera, D.; Gutman, D.; Barber, G.N.; Olson, J.K.; Smith, J.A. Endoplasmic reticulum stress regulates the innate immunity critical transcription factor IRF3. J. Immunol. 2012, 189, 4630-4639. [CrossRef]

55. Asai, T.; Ueda, T.; Itoh, K.; Yoshioka, K.; Aoki, Y.; Mori, S.; Yoshikawa, H. Establishment and characterization of a murine osteosarcoma cell line (LM8) with high metastatic potential to the lung. Int. J. Cancer 1998, 76, 418-422. [CrossRef]

56. Takahashi, Y.; Yasui, T.; Minami, K.; Tamari, K.; Hayashi, K.; Otani, K.; Seo, Y.; Isohashi, F.; Koizumi, M.; Ogawa, K. Carbon ion irradiation enhances the antitumor efficacy of dual immune checkpoint blockade therapy both for local and distant sites in murine osteosarcoma. Oncotarget 2019, 10, 633-646. [CrossRef]

57. Kimura, A.; Kishimoto, T. IL-6: Regulator of Treg/Th17 balance. Eur. J. Immunol. 2010, 40, 1830-1835. [CrossRef]

58. Yagi, M.; Arentsen, L.; Shanley, R.M.; Rosen, C.J.; Kidder, L.S.; Sharkey, L.C.; Yee, D.; Koizumi, M.; Ogawa, K.; Hui, S.K. A dual-radioisotope hybrid whole-body micro-positron emission tomography/computed tomography system reveals functional heterogeneity and early local and systemic changes following targeted radiation to the murine caudal skeleton. Calcif. Tissue Int. 2014, 94, 544-552. [CrossRef]

59. Ebner, D.K.; Kamada, T. The Emerging role of carbon-ion radiotherapy. Front. Oncol. 2016, 6, 140. [CrossRef]

60. Schmittgen, T.D.; Livak, K.J. Analyzing real-time PCR data by the comparative C(T) method. Nat. Protoc. 2008, 3, 1101-1108. [CrossRef]

61. Ruiz, V.E.; Sachdev, M.; Zhang, S.; Wen, S.; Moss, S.F. Isolating, immunophenotyping and ex vivo stimulation of CD4+ and CD8+ gastric lymphocytes during murine Helicobacter pylori infection. J. Immunol. Methods 2012, 384, 157-163. [CrossRef]

(C) 2020 by the authors. Licensee MDPI, Basel, Switzerland. This article is an open access article distributed under the terms and conditions of the Creative Commons Attribution (CC BY) license (http://creativecommons.org/licenses/by/4.0/). 